\title{
The Kohimārama Conference of 1860: A Contextual Reading
}

LACHY PATERSON

For four weeks in mid-1860, Māori chiefs gathered at the Anglican missionary centre at Kohimārama near Auckland, having been invited by Governor Browne to gather and discuss issues with government representatives. The Kohimārama Conference was a significant political event at which Māori voiced their opinions on a number of topics, but the meeting's relevance to the government was relatively short-lived, its importance effectively marginalized by subsequent events, in particular the 1863-1872 conflicts, confiscation, the Native Land Court, and other colonial developments. However, this month-long meeting retained or regained a significance within Māoridom, with some Māori leaders of the last quarter of the nineteenth century referencing the kawenata (covenant) of Kohimārama in their efforts to assert rangatiratanga within their relationship with the Crown. Historians largely ignored the event until Claudia Orange's 1979 New Zealand Journal of History article entitled 'The Covenant of Kohimarama: A Ratification of the Treaty of Waitangi'. ${ }^{1}$ As the title indicates, Orange places the conference firmly within a Treaty of Waitangi paradigm. Indeed, Orange's work, together with some other pivotal texts emerging from the $1970 \mathrm{~s},{ }^{2}$ has been instrumental in creating a Treaty-framed historiography, and her reading has been further processed within other academic or governmental writings, especially Waitangi Tribunal reports, although a few counter-interpretations have also appeared, as discussed below.

While acknowledging that Kohimārama has a place within Treaty historiography, this essay seeks a broader reading of what the conference meant at the time. As Mark Francis states, 'intra-communal rituals were not only dramatic, they were functional as well. They were designed to create fear or awe among a native group, and, at the same time, make the group well-disposed towards the British.' ${ }^{3}$ In 1860 the government was attempting to assert its rule over Māori through both moral suasion and military aggression and staged the Kohimārama Conference, with over 200 supposedly friendly chiefs participating, as an act of political theatre aimed at both the players and the many observers. Even if fear and awe were not fully realized, the government endeavoured to project an image of Māori accord with its policies. It then re-presented the event textually to a wider Māori audience through its bilingual newspaper, Te Karere Maori, with 
conference attendees receiving the relevant issues bound in book form. ${ }^{4}$ The conference did not go unnoticed among the Pākehā population, with reports published in their newspapers across the country. Using these texts, and other archival sources, this essay argues that, for the Crown, Kohimārama was less a renewal of its 1840 covenant with Māori than an event, which took place in a time of political and military stress, by which the government attempted to gain Māori acquiescence of its policies, and to publicize this to a wider Māori and Pākehā audience.

Claudia Orange, in her article 'The Covenant of Kohimarama' and her book, The Treaty of Waitangi, sees Kohimārama almost exclusively in terms of chiefs striving to assert their mana, or construct a partnership with the state within a Treaty framework. She stresses the governor's opening speech which 'dwel[t] at length on the Treaty's clauses [and] repeat[ed] the pledges made in $1840,{ }^{5}$ and that the native minister, Donald McLean, encouraged participants to consider the conference as " "a fuller ratification", which culminated in "the final [sic] resolution of the conference, effectively a ratification of the treaty c[oming] to be known as the Kohimarama covenant'. ${ }^{6}$ Orange is relatively circumspect on Crown motives, stating 'that the Governor was threatening a withdrawal of Crown obligations under the treaty, and making that agreement conditional on a continuing Maori acceptance of government authority'? However, she also implies that Donald McLean, who presided over the conference, in his reiteration of the governor's speech 'played down the crucial transfer of power involved' and that his translation of Māori 'giv[ing] up completely . . . all the rights and power of government' failed to convey explicitly 'the abstract national sovereignty' the Crown claimed. ${ }^{8}$ Although she makes clear that McLean was attempting to manipulate the conference in order to gain the results the government desired, her assessment that his referring to Kohimārama as 'a fuller ratification' of the Treaty was an endorsement of Māori aspirations fails to recognize that some present may have interpreted it as a ratification of state control. ${ }^{9}$

Subsequent writers, some with rather less realistic assessments of Kohimārama, have not always matched Orange's relative moderation, and seek to unequivocally posit the conference within a tino rangatiratanga discourse. For example, one Waitangi Tribunal report suggests that Māori chiefs 'met at Kohimarama (Auckland) to debate and endorse the Treaty, debate the Governor's proposed policies, and offer him their collective advice' as if the Crown was making a genuine attempt at partnership. It states, 'Gore Browne appears to have envisaged genuine power-sharing with an annual "Native Conference", a 'model for how the Crown could or should have acted' and 'a virtual Maori parliament', and 'the continuation and evolution of the Kohimarama Conference would have made Maori powerful at the 
heart of the State, the top tier of government'. ${ }^{10}$ The Orakei report even suggests that Ngāti Whātua chief Pāora Tūhaere was given, in the spirit of partnership, the honour of chairing the 1860 meeting..$^{11}$ The Treaty becomes central to Kohimārama, with one recent government document stating:

Discussions centered on the meaning of the Treaty, and proceedings of the meetings convey the chiefs' understanding of the nature of the Treaty relationship. A unanimous resolution - the Kohimarama Covenant - was passed by the conference, recognising the sovereignty of the Crown, an act that has been described as a 'ratification of the Treaty' which affirmed the rangatiratanga of the chiefs. ${ }^{12}$

Such is the positivity surrounding Kohimārama that one academic describes the meeting as perhaps New Zealand's 'first national health hui'. ${ }^{13}$ However, as the government's own rhetoric and subsequent events make clear, any kind of autonomy that might devolve to Māori would be restricted and under Crown control. ${ }^{14}$ Given such readings, it is perhaps surprising that a few right-wing commentators have also delved into the reported speeches from Kohimārama to come up with completely contrary interpretations. David Round, for example, suggests that Kohimārama provides ample proof of Māori acceptance of Crown sovereignty, and the omission of any discussion of the conference in the nation's history books 'contributes to the widely-perpetrated anti-colonial understanding of our history and general white liberal guilt complex'. ${ }^{15}$ A similar unnuanced reading, with selected excerpts from the English translation of the speeches, graced a copy of Investigate magazine to suggest that chiefs had rejected tino rangatiratanga in $1860 .{ }^{16}$ Kohimārama also now features in the right-wing Centre for Political Research's anti-Treaty rhetoric. ${ }^{17}$

It may well be that those who seek to find validation for current stances on the Treaty within the recorded speeches of chiefs who attended Kohimārama are missing the point, ${ }^{18}$ and this essay seeks to provide a more contextualized reading. Neither the Crown, nor the Māori who attended the conference in 1860, were worried so much about the Treaty of Waitangi as about other pressing political concerns. While some chiefs did discuss the Treaty, they were a minority: of the 371 recorded speeches and published papers given by Māori, only 26 mentioned the Treaty at all. ${ }^{19}$ None of eight resolutions agreed to by the chiefs at the close of the conference actually referenced the Treaty, although the first (which Orange considers 'in effect a ratification of the treaty') affirmed 'the mana of the Queen' while alluding to the conference itself (not the Treaty) as a kawenata. ${ }^{20}$ However, the Treaty was not the primary reason the chiefs met. As other historians have noted (even when their focus has been on the Treaty), Governor Browne invited chiefs to attend mainly to gain their support over the war in Taranaki and 
against the Kinngitanga, ${ }^{21}$ or to gain 'subordination of the native race to the authority of the Crown'. ${ }^{22}$ These issues, and that the conference served as an immense propaganda exercise on the part of the government to achieve these aims, comprise the context within which to read the conference.

When Māori chiefs met at Kohimārama the Treaty certainly came up for discussion. Mason Durie has identified changes in both Crown and Māori attitudes to the Treaty over time. Before 1860, Māori, whose mana was still real and substantive, maintained a relative indifference to the Treaty. ${ }^{23}$ It was the Crown, not yet exercising condign power over Māori, who pursued their Treaty right, as they saw it, of sovereignty. Thus Governor Browne, whose opening address framed subsequent discussion that followed on the Treaty, while expounding the property rights Māori derived from the Treaty (based on the English-language version of the Treaty) also explained those benefits as the price they had to pay for the Treaty.

4. In return for these advantages the Chiefs who signed the Treaty of Waitangi ceded for themselves and their people to Her Majesty the Queen of England absolutely and without reservation all the rights and powers of sovereignty which they collectively or individually possessed or might be supposed to exercise of possess [translation: source].

McLean's translation in Māori can be back-translated as:

4. So, the chiefs who signed their names to that document, the Covenant of Waitangi, were intending it as the price for those benefits they received. That was a resolution [ritenga] for themselves and their tribes, that they give up completely to the Queen of England all the rights [tikanga] and power [mana] of government from them all, and from each of them, and all things like that considered to be theirs [translation: LP]. ${ }^{24}$

The translation, which Orange believes glosses over the transfer of 'sovereignty', perhaps struggles with the limited Māori-language political lexicon at the time, but should be read in the context of his avoidance of the term 'tino rangatiratanga', and the governor's remarks on the Kinngitanga in his opening address. This movement had not only established its own independent leadership, but its supporters had fought against the Crown in Taranaki leading Browne to describe the movement as 'an act of disobedience and defiance to Her Majesty which cannot be tolerated [source]. ${ }^{25}$ Adding that those Māori who did not accept the Crown's authority risked losing the Treaty's guarantees of protection, Browne threatened Māori that 'the result will be that many evils will befall the Māori people, and the destruction through which they will disappear [LP]. ${ }^{26}$

The Taranaki war, and the risk of it escalating, were of immediate political importance to the government. Race relations were at a particularly low ebb in 1860. Many Māori believed they had not experienced the expected 
fruits of the two preceding decades of colonization, and that the government was more concerned with purchasing land for settlers than providing good governance for Māori. Officials' land-buying efforts often led to tensions, sometimes war, between differing Māori groups contesting ownership. North Taranaki in particular was the scene of a number of murders and fights about which the government appeared to have little concern. Some Māori tribes sought to combine in order to resist land sales, and maintain peace and stability within their communities. This trend to amalgamate culminated in the formation of the Kingitanga in the late 1850s, a loose confederation with strong support in the central North Island, and moderate backing in other parts of the island south of Auckland. In 1859 a low-ranking Te Āti Awa chief offered land at Waitara for sale to the government. With minimal investigation into the title and in the face of opposition from the tribal leader, Wiremu Kīngi Te Rangitāke, Governor Browne pressed ahead with the purchase, precipitating the first Taranaki war in March 1860. Browne chose to interpret Te Rangitāke's assertion of chiefly rights and subsequent resistance not as a defence of his land rights, but as a challenge to the government's sovereignty. Te Rangitāke in his turn appealed to the Kinngitanga for help. By the time the Kohimārama Conference convened, government forces had won a debatable victory at Waireka, and just been beaten decisively at Puketakauere in June, with the settlers effectively hemmed in to the town of New Plymouth. Even as the conference was closing, Governor Browne acknowledged privately that 'the Taranaki news is worse and worse'. ${ }^{27}$

With both neighbouring Taranaki tribes and Kīngitanga forces joining the fight against the Crown, the government was concerned lest other tribes also decided to enter the fray. Eliza Stack noted in her diary at the time 'the suspicion which had taken root in the native mind that the English intended to dispossess them of their lands' ${ }^{28}$ One month into the war McLean suggested a conference, stating that it was 'a means of preventing what would be much more costly a general native war. It would be imprudent, at the present juncture, that those Natives whose feelings are friendly should not be reassured \& confirmed in their friendly sentiments. ${ }^{29}$ On the conclusion of the conference, as he contemplated a second meeting, he described it as 'a safety valve' and 'the means ... of imbuing the Native mind with correct views as respects measures of the Government to the success of which their concurrence and cooperation is absolutely essential', as a 'means [by which] Her Majesty's aboriginal subjects may be more effectively controlled and governed'.$^{30}$ In a similar tone, C.W. Richmond, the minister of native affairs, considered more conferences necessary because 'It could not be expected to bring the Natives to our views at once. ${ }^{31}$ Francis Dillon Bell also considered that the conference had been an effective counter against the Kinngitanga, and that a further meeting might discuss individualized land tenure. ${ }^{32}$ 
If the governor's opening speech failed to awe or frighten Māori, then certainly the rest of the conference's organization was designed to gain a better disposition from those attending. The conference was probably not too onerous, with chiefs assembling for about three hours most days, with weekends off. Certainly, they were reasonably cared for. Although the Southern Cross had feared the 'gluttony' of a Māori feast, ${ }^{33}$ the Wellington Independent happily reported:

The lodgement for the Chiefs was good, yet not extravagant; the provision was substantial and abundant, yet not luxurious or too profuse. The whares were weatherboard, and raised a sufficient height to keep the inmates free from the effects of damp. The provision was good 'John Bull' fare - but no more liberal than Maori Chiefs made for their Pakeha guests. ${ }^{34}$

The chiefs had been conveyed on chartered vessels, ${ }^{35}$ lived at Kohimārama in Pākehā-style houses, ate Pākehā food, and engaged in kōrero according to Pākehā rules of engagement. There appears to have been little of the excess and ritualistic pomp that accompanied assemblies in colonial India in which British governors sought to elevate themselves above their indigenous 'subjects'. ${ }^{36}$ For the most part McLean represented the face of government, with the governor present only to open and close the conference. As the meeting was ending, McLean suggested to Browne that 'It would have an excellent effect with the chiefs if you would come down to dine with them tomorrow.' McLean was careful to project sufficient, but not excessive, gubernatorial dignity, suggesting that 'something in the way of distinction should be worn by you but not full uniform'. ${ }^{37}$ The governor's table would be covered with a cloth, but he would share the same fare as the chiefs. This was an opportunity for Māori to get close and converse with the governor with what might appear to be relative equality. Te Karere Maori suggested the chiefs 'really appreciated that sign of love [LP]'. ${ }^{38}$ One chief compared the dinner to the Last Supper, in the way that those present were now connected with the governor.

Do you not consider that we have dined in company with the Governor, and that he has spoken words to you? If one tribe take food with another tribe that implies the establishment of love (between them). In like manner, Christ, when he had finished his work, took bread with his disciples. This was the way in which he confirmed his love to his apostles. In what direction can you fly now? for you have taken food with the Governor [source]. ${ }^{39}$

The chiefs, as McLean well knew, were under an obligation to the government. It is perhaps not surprising that Rēnata Kawepō, who had refused to attend, disparagingly described those who did as 'Lick-plates'. ${ }^{40}$ 
The conference, as participatory performance, was paired textually with a printed version of the speeches. It is not altogether clear to what extent these present the complete speeches - certainly there was almost none of the banter one would expect at this sort of meeting - but the government was keen to give an impression that the chiefs could speak openly, and reported that minutes were returned to chiefs to check they were happy with what was recorded. ${ }^{41}$ The speeches needed to appear correct, as they were disseminated to a wider Māori audience through the government's bilingual fortnightly or monthly newspaper, Te Karere Maori, although it appears that the conference secretary, Walter Buller, 'condensed as much as possible, but gave the Governor's messages and [McLean's] speeches in full' . ${ }^{42}$ That the government considered news of the conference important in 'imbuing the Native mind with correct views' can be seen in the extent of its coverage, and that Browne's opening speech was published and disseminated just four days after the start of the meeting. Although the conference ran for only four weeks, the newspaper's content was devoted to the event for five months. When normal issues were generally about 12 pages long, the six issues on the conference comprise 298 pages, averaging almost 50 pages per issue. ${ }^{43}$ Just as the government's newspaper sometimes utilized letters from Māori supporting its position, the conference was about not just getting chiefs publicly on side, but ensuring that they were seen to do so in the printed record.

Although Te Karere Maori denied that the conference was called primarily over Taranaki and the Kinngitanga, ${ }^{44}$ no one was under any illusion. As Waka Nene stated, 'I am searching for the cause of why we are here; it is with Te Rangitāke, or the King? [LP]. ${ }^{45}$ These political and military objectives were closely entwined with the overall colonial project. As one Pākehā spectator (unnamed but perhaps a government official) at the conference noted, the governor had invited the chiefs to Kohimārama with three main aims:

1st. To the suppression of existing war and the prevention of such evils in the future.

2 nd. To the more speedy settlement by Europeans of what are now purely native districts.

3rd. To the amelioration of the natives themselves - their advancement in the scale of civilivation [sic], and their amalgamation (so to speak) with their European neighbours.

He added, "The "thin edge of the wedge" has been inserted and those who are conversant with native affairs can fairly appreciate the advantage thus gained. ${ }^{46}$

In the first few days the chiefs displayed a general sympathy towards Te Rangitāke and Te Āti Awa, or at least an anti-war rhetoric that arbitration 
was preferable to war, and McLean endeavoured to steer the conference in the right direction. Just over a week into the conference, to counter proTe Rangitāke sentiments, the native secretary spent a whole day giving a history of the North Taranaki region, from the time of the 1839 New Zealand Company purchase to the present, detailing the various times that both Taranaki Māori and Waikato had been paid for land there, even reading out a number of documents verbatim.

The Taranaki people are now asserting a claim to territory which has become the property of the Government. Waikato has taken up arms to hold that which their own chiefs gave to the Europeans; spreading it forth for their acceptance in the light of day and under the shining sun of heaven. Had it been territory not previously touched or broken into, the case would have been different, but it was not so. The land has been consumed; it cannot return to its original state any more than the ashes of a dead fire can be rekindled. Let the Chiefs of the Council look at the facts of the case and consider them well [source]. ${ }^{47}$

McLean very carefully avoided discussion of the military situation, with just a brief mention of the Puketakauere disaster which he disingenuously suggested had resulted in heavy Māori losses. ${ }^{48}$ Such was McLean's manipulation of the facts that many Māori appeared to swing in behind the government position. Some chiefs wanted to go to Taranaki to talk sense to Te Rangitāke, but McLean dissuaded them. ${ }^{49}$ Ultimately, the government was able to project an image of chiefly support for its stand on the Waitara dispute, with the passing of a resolution on Taranaki: 'That this Conference having heard explained the circumstances which led to the war at Taranaki, is of opinion that the Governor was justified in the course taken by him; that Wiremu Kingi Te Rangitake himself provoked the quarrel; and that the proceedings of the latter are wholly indefensible [source]. ${ }^{50}$ Although moved and seconded by Māori, the wording in both languages suggests that these were drafted by government officials rather than Māori themselves, as does a letter from McLean to Browne. ${ }^{51}$ In the reporting of the vote, Te Karere Maori was able to note that even a chief renowned for being anti-government voted for this resolution:

Mr. McLean said again, 'Let those Chiefs who approve lift up their hands.' There was a good deal of confusion. Te Makarini Te Uhiniko got up and said, 'My reason for rising is that I do not see many hands lifted up.' Herewini Te Amohau, rising up, addressed Te Makarini Te Uhiniko thus: 'Your opposition to the Governor is of old; that seems to be your chief work.' Te Makarini replied, 'I am not opposing now, for I lifted up my hand.' [source] ${ }^{52}$ 
Ultimately the government was able to claim that the chiefs present unanimously signed a document agreeing to the resolutions, which included recognition of the Queen's mana and condemnation of the Kinngitanga, with just three chiefs objecting to the resolution on Taranaki.

The conference largely fulfilled the government's desires, notwithstanding the huge cost of at least $£ 4,250 .{ }^{53}$ They were keen to project an image that most of the chiefs accepted the governor's actions in Taranaki, and that all present had unanimously condemned the Kingitanga, as seen in Te Karere Maori's reporting that 'These resolutions, with one exception, were carried unanimously. We are, therefore, pleased to find that the foolish project of a "Maori King," to which we adverted in a former number, is so unhesitatingly condemned by a large body of most influential and intelligent Maories [source]. ${ }^{54}$ Te Haeata, the newspaper of the Methodist Mission, which gave strong support to the government over Taranaki, echoed similar sentiments:

The opinion, that of most of the people of the Conference, is that Te Rangitāke is the cause of the trouble at Taranaki. . . .

What they [Māori] really want is to stick with the Pākehā, that they should love the Pākehā and the Pākehā should love the Māori. . . .

The establishment of the king was an issue of discussion of that Conference. There was great objection to this thing. To them, this was the cause of the troubles of this country. . . .

... they thought all Māori should live under the protection of the Queen, there should be one law for the country, for both Māori and Pākehā, the same for both [LP]..$^{55}$

Despite these assertions, some coverage of the conference in the settler press made it clear that not all chiefs had been convinced by government arguments over Taranaki. The Anglican missionary voice was generally critical of the war, and Hugh Carleton, the son-in-law of Reverend Henry Williams and editor of the Daily Southern Cross, was prepared to cast doubt on the government's claims: ${ }^{56}$

On the Chairman putting the Resolution, about one third held up their hands. (Considerable confusion). Chairman called attention to the fact that in the earlier part of the Conference they had blamed (Whakahe) the Governor, for the war at Taranaki; but that he having enlightened them on the question at issue, he understood that they were now convinced to the contrary, (some irregular talk among the Natives - private conversation between the Chairman and the assistant Native Secretary). Chairman again put Resolution III. About the same number (one third) held up their hands, (further confusion - some little talking). Chairman did not 
call upon those who disapproved of the motion to put up their hands, but called upon W. TAMEHANA to move Res. IV. ${ }^{57}$

Soon after, the Cross published a letter from Reverend Robert Burrows, an Anglican missionary. Burrows reported that, despite just one third support for the resolution by show of hands, 'after the Chairman had declared the Conference closed . . . the great majority of these men had been induced to attach their signatures to those Resolutions as a whole', and he learnt that 'some of them had afterwards expressed their ignorance of what they had signed'. He remonstrated with officials at the Native Office, but then expressed surprise at claims in the New-Zealander that the chiefs had adopted all the resolutions. As one "conversant with the native language, and the working of the native mind', he believed that the chiefs 'were not at all prepared to throw the whole onus of that war upon the shoulders of "Wiremu Kingi.",

The Native Conference had not been sitting many days before it appeared evident to those, that the unhappy Taranaki war was not only uppermost in their thoughts, but some of the chiefs present began to express their minds very freely and to plead for a cessation of hostilities. It soon became evident that nothing short of reply from the Governor on the subject would satisfy them. On the 19th of July the Message of his Excellency was printed in the 'New Zealander' of Saturday last, was read to them, prefaced by a long account from Mr. McLean, respecting the Taranaki land question, which also appeared in the above named paper. The Chairman's address, and the Governor's Message together, tended to enlighten some, and to silence others, but many who were silent were not satisfied, and in this state I believe they remained up to the close of the Conference. ${ }^{58}$

The Cross published a rebuttal from H.T. Clarke, the resident magistrate of Bay of Plenty, in which he argued that the chiefs had had ample time to discuss the resolutions which 'were then eagerly signed by one hundred and seven of the Chiefs'. ${ }^{59}$

Aspersions were also cast that government had largely bought the support of the chiefs. The Cross thought not only that the government's hospitality was likely to have moderated criticism from the chiefs, but also that 'the meeting had been under the influence of presents ${ }^{90}$ Near the end of the conference, Mātene Te Whiwhi asserted his loyalty to the Crown, then stated, 'Here also is a word of mine: do not be grieved Mr. McLean. Let the warmth rest upon the Maori, as it does upon the Pakeha', which Te Karere glossed with '[Meaning that the members of the Conference should receive pay.] [source]'. ${ }^{61}$ This a correspondent to the Southern Cross interpreted as: 
A Southern Chief, of celebrity, spoke somewhat to this effect. The chiefs having been called to the Conference by the Governor to express themselves in his favour, they had responded to his call, and uttered words in his rooms favourable to his policy, therefore a reward should be given to each chief in the shape of hard cash. This truthful one was confronted by the Land Commissioner [McLean], and the matter hushed up as speedily as possible. ${ }^{62}$

The issue continued after the conference, with claims from the Wellington Independent that chiefs from their province had received shotguns ${ }^{63}$ and questions in Parliament on 'the amount of money paid as presents'. ${ }^{64}$ Changing circumstances soon made all such discussion irrelevant. Soon after, Grey replaced Browne as governor and no more nationwide conferences were called. Kohimārama, at least for Pākehā, was soon forgotten.

The third criticism, trumpeted by the parliamentary 'opposition', was that the assembled chiefs were not representative of Māori as a whole. William Fox, as reported in the Southern Cross, suggested, 'the Native Secretary had leave to select those Natives who suited his purpose', and James Fitzgerald described them as 'a happy family'. Fox also suggested that McLean had failed to invite some important chiefs, and others had been asked too late. ${ }^{65}$ Chiefs came and went, with 112 listed as present on the first day, perhaps a hundred arriving subsequently and 107 still remaining to 'unanimously' sign the resolutions on the final day. ${ }^{66}$ Taranaki was not represented, and Waikato barely so. While it is fair to say that most areas had some chiefs present, some had much greater representation than others. The government put the non-attendance down to a number of factors: there had been a recent epidemic; Taranaki chiefs did not want to leave home at a time of war; and Waikato were mourning the death of Te Wherowhero. ${ }^{67}$ It is likely that some refusals stemmed from more political motives. For example, only five Hauraki chiefs from 21 invited accepted the offer, a stance Paul Monin attributes to 'diminished confidence in government Maori policy and, conversely, increased support for the Kingitanga' ${ }^{6}{ }^{6}$

Māori had a variety of attitudes towards the conference. Some Māori were clearly unenthusiastic about Kohimārama and talk of a further meeting, as the government was aware. Grey, in deciding not to stage a second event in 1861, considered it not 'wise to call a number of semi-barbarous Natives together to frame a Constitution for themselves'. ${ }^{69}$ He claimed that, 'when the last Conference was summoned to Kohimarama, some Natives refused to attend it; other Chiefs of importance threw, and still throw, ridicule upon the whole affair'. Waikato, he asserted, had been offended by the remarks from some of their former enemies, but would also be unwilling to cooperate in a government-run institution, an act which would run counter to their own claims to sovereignty. ${ }^{70}$ Thomas Smith, as assistant native secretary, 
also cautioned Browne against a second conference, as a chief chosen would be placed 'in an invidious position, and that by identifying him with the Government under present circumstances it would tend to impair the influence which he might otherwise exercise'. ${ }^{71}$ On the other hand, some chiefs may have enjoyed a trip to Auckland and hospitality at the state's expense; others the opportunity to mix with and debate important issues with other chiefs and government officials, or to assert their loyalty in uncertain times. Attitudes will have depended on particular tribal responses to government policy and the political situation. Bay of Islands chiefs, for example, subsequently held meetings to discuss what had transpired at Kohimārama. As H.T. Kemp reported, rather obliquely, to McLean, 'The opening address of his Excellency was publicly read and freely commented on by the people present, who seemed to take great interest in it. ${ }^{72}$ Pāora Tūhaere, with mana whenua over Kohimārama itself, unsuccessfully requested a second conference in 1869 , and subsequently organized his own meetings in the $1870 \mathrm{~s}$ and $1880 \mathrm{~s} .{ }^{73}$ Chiefs at the conference would have been well aware of government motives and exhibited what Michael Allen has termed (in his discussion of Crown-Māori interaction of mid-1880) 'political ambivalence'. When encountering Pākehā officialdom, Māori leaders might contest specific policies but would also pragmatically acknowledge the Crown's mana, or request governmental redress for their grievances. ${ }^{74}$

Outside of military actions, the Kohimārama Conference was perhaps the largest and most expensive single event the government had ever directed towards Māori in the first few decades of colonial rule, in terms both of the actual event and its accompanying printed material. Its purpose was to portray a racial inclusiveness bounded within British supremacy. As the magistrate A.J. Johnston told McLean, the conference 'has not been useless' and showed that government 'moderation' was desirable once 'its power to quell insurrection had been made manifest'. ${ }^{75}$ McLean, as native secretary, stage-managed and directed proceedings, and was not above massaging facts, as in his narration of Taranaki's recent history, or in how the resolution on the Taranaki war was presented textually to the public. Māori attitudes were divided as to the appropriateness of the conference, and Pākehā contemporaries differed in assessments of its effectiveness. While the chiefs were meeting, one writer for the Colonist considered that 'the government are most anxious that their native conference should appear worth the pains they have taken to bring it about', but could not hide that it was 'a complete failure as well as thorough sham'. ${ }^{76}$ A correspondent to the Wellington Independent considered the money well spent, and 'the most favorable results may be anticipated' ${ }^{77}$ as did Governor Browne himself. ${ }^{78}$ However, the Colonist was perhaps closer to the truth when suggesting that the resolutions on Taranaki and the Kīngitanga 'will be useful to us 
at present; but too much reliance must not be placed upon them'. ${ }^{79}$ In more recent times Kohimārama has often been viewed purely through a Treaty lens, either as a proto-Treaty-compliant partnership on one side or evidence of Māori submission to Crown sovereignty on the other. Such views reflect the obsessions of our own time rather than those of Māori and Pākehā in 1860 regarding the Taranaki war and the Kīngitanga, and privilege fragments of the bare textual record rather than a fuller and more contextualized reading of the event. McLean and some of the chiefs did discuss the Treaty, but Browne had effectively laid the foundation for that debate by offering a stark choice of accepting the Crown's sovereignty or the possibility of racial destruction. The government's aim for the rest of the conference was about aligning the chiefs present to its side, or at least convincing both Māori and Pākehā that they had managed to achieve this.

I would like to acknowledge those who provided feedback to an oral presentation of this material at Massey University, 2 June 2011, and Tony Ballantyne, John Stenhouse and Angela Wanhalla who read drafts of this text and generously gave many helpful comments.

1 Claudia Orange, 'The Covenant of Kohimarama: A Ratification of the Treaty of Waitangi', New Zealand Journal of History (NZJH), 14, 1 (1980), pp.61-82.

2 Ruth Ross, 'The Treaty of Waitangi: Texts and Interpretations', NZJH, 6, 2 (1972), pp.129-57.

3 Mark Francis, Governors and Settlers: Images of Authority in the British Colonies, 1820-60, Christchurch, 1992, p.68.

4 Proceedings of the Kohimarama Conference, Comprising Nos. 13 to 18 of the Maori Messenger: Nga Mahi a te Runanga ki Kohimarama, ara, kei nga Karere Maori, no.13 tae noa ki te 18, Auckland, 1860.

5 Claudia Orange, The Treaty of Waitangi, Wellington, 1987, p.145.

6 Ibid., pp.148-9.

7 Orange, 'The Covenant of Kohimarama', pp.65.

8 Orange, The Treaty of Waitangi, p.147. A recent biography of McLean also utilizes this interpretation: see Ray Fargher, The Best Man Who Ever Served the Crown? The Life of Donald McLean, Wellington, 2007, p.206.

9 Orange, The Treaty of Waitangi, pp.149-50.

10 Waitangi Tribunal, 'He Maunga Rongo: Report on Central North Island Claims: Stage One.', ch.4, 2008, pp.61, 63, 64, 77, 88, www.waitangitribunal.govt.nz, accessed 24 March 2011.

11 Waitangi Tribunal, 'Report of the Waitangi Tribunal on the Orakei Claim', ch.5, http:// www.waitangi-tribunal.govt.nz/scripts/reports/reports/9/3A6792D0-2FAA-4E6F-99D4 -80E4B8BF0E4E.pdf, accessed 24 March 2011.

12 Te Puni Kōkiri, 'A Guide to the principles of the Treaty of Waitangi as Expressed by the Courts \& the Waitangi Tribunal', p.42, http://www.tpk.govt.nz/en/in-print/our-publications 


\section{Journal of New Zealand Studies}

/publications/he-tirohanga-o-kawa-ki-te-tiriti-o-waitangi/download/tpk-treatyhistorical -2001-en.pdf, accessed 24 March 2011.

13 John Waldon, 'The Treaty and the Rights of the Child: The Case Study of Hepatitis B', in Stuart Birks, ed., Children's Rights and Families: Proceedings of the Social Policy Forum 2001, Centre for Public Policy Evaluation, Massey University, 2001, http://cppe .massey.ac.nz/papers/cppeip10/cppeip10.pdf, accessed 24 March 2011.

14 Fargher, The Best Man, p.205. See also Te Manuhiri Tuarangi (TMT), 15 August 1861, pp.1-9.

15 David Round, 'Claims of Maori Sovereignty Absurd', BreakingViews.co.nz, http:// breakingviewsnz.blogspot.com/2010/06/david-round-claims-of-maori-sovereignty.html, accessed 30 March 2011.

16 Ian Wishart, 'Voices From The Past: What Maori Really Wanted from the Treaty', Investigate, August 2004, pp.34-48.

17 Ross Baker, 'Ngapuhi Ceded Their Territories in 1840', New Zealand Centre for Political Research, http://www.nzcpr.com/soapbox.htm, accessed 30 March 2011.

18 Although historians have not, to my knowledge, critiqued Orange's interpretation of Kohimārama before, there has been considerable discussion on the nature of Treatyframed histories, and the relationship between legal processes and Treaty history, for example in the New Zealand Journal of History. See M.P.K. Sorrenson, 'Giving Better Effect to the Treaty', NZJH, 24, 2 (1990), pp.135-49; Alan Ward, 'History and Historians Before the Waitangi Tribunal', NZJH, 24, 2 (1990), pp.150-67; James Belich, 'Hobson's Choice', NZJH, 24, 2 (1990), pp.200-7; Paul McHugh, 'Law, History and the Treaty of Waitangi', NZJH, 31, 1 (1997), pp.38-57; Arthur J. Rae, 'Aboriginal Title and Treaty Rights Research: A Comparative Look at Australia, Canada, New Zealand and the United States', NZJH, 37, 1 (2003), pp.5-21; Jim McAloon, 'By Which Standards, History and the Waitangi Tribunal', NZJH, 40, 2 (2006), pp.194-213; Giselle Byrnes, 'By Which Standards, History and the Waitangi Tribunal: A Reply', NZJH, 40, 2 (2006), pp.214-30; Michael Belgrave, 'Looking Forward: Historians and the Waitangi Tribunal', NZJH, 40, 2 (2006), pp.194-250; W.H. Oliver, 'A Reply to Jim McAloon', NZJH, 41, 1 (2007), pp.82-87.

19 In total there were 371 text segments generated by the chiefs at Kohimārama recorded in the Proceedings, 338 of which were speeches. In addition, chiefs were asked to respond in writing to Browne's opening speech, which resulted in 33 written reports.

20 Orange, The Treaty of Waitangi, p.149; Te Karere Maori (TKM), 15 August 1860, p.6. Note: original English texts or translations are indicated as [source]; modern translations by the author as [LP]. 'That this Conference takes cognizance of the fact that the several Chiefs, members thereof, are pledged to each other to do nothing inconsistent with their declared recognition of the Queen's sovereignty, and of the union of the two races; also to discountenance all proceedings tending to a breach of the covenant here solemnly entered into by them [source]'; 'E whakaae ana tenei Runanga, i te tikanga o nga rangatira i noho ki roto; kua tino whakaae nei tetahi ki tetahi kia kaua rawa he pakanga ketanga i runga i te kupu kua whakapuakina nuitia mo te mana o te Kuini, mo te whakakotahitanga hoki o nga iwi e rua; a kua whakaae nei tetahi ki tetahi kia whakahengia nga mahi katoa mana e taka ai ta ratou kawenata tapu kua whakatakotoria ki konei.'; 'This conference is in agreement, on the basis of the chiefs who participated, [they] affirm, one to another, not to break the peace, on account of the strongly voiced declaration concerning the authority of the Queen, and the unity of the two races, and each agrees to oppose all acts which might cause the sacred covenant entered into here to fall [LP].' 
21 For example, Michael Belgrave, Historical Frictions: Maori Claims \& Reinvented Histories, Auckland, 2005, p.71; Basil Keane, 'Kotahitanga', in Malcolm Mulholand and Veronica Tawhai, eds, Weeping Waters: The Treaty of Waitangi and Constitutional Change, Wellington, 2010, p.180; Danny Keenan, Wars Without End, Auckland, 2009, p.205; Vincent O'Malley, Agents of Autonomy: Maori Committees in the Nineteenth Century, Wellington, 1998, p.20; Ranginui Walker, Ka Whawhai Tonu Matou: Struggle Without End, Auckland, 1990, p.114; Vincent O’Malley, Bruce Stirling and Wally Penetito, The Treaty of Waitangi Companion: Māori and Pākehā from Tasman to Today, Auckland, 2010, p.99; Keith Sinclair, The Origin of the Maori Wars, Auckland, 1976, pp.230-1; Alan Ward, 'McLean, Donald', Dictionary of New Zealand Biography. Te Ara - the Enclopedia of New Zealand, updated 1-Sep-10, http://www.TeAra.govt.nz/en /biographies/1m38/1.

22 Fargher, The Best Man, p.205.

23 Mason Durie, Te Mana, Te Kāwanatanga: The Politics of Māori Self-Determination, Auckland, 1998, p.178.

24 TKM, 14 July 1860, pp.5-6. “4. Na, he meatanga ano ta nga Rangatira Maori i tuhituhi nei o ratou ingoa ki taua Pukapuka ki te Kawenata o Waitangi, hei ritenga ia mo enei pai i whakawhiwhia nei ratou; ko taua meatanga he meatanga mo ratou mo o ratou iwi hoki;--tino tukua rawatia atu ana e ratou ki te Kuini o Ingarani nga tikanga me nga mana Kawanatanga katoa i a ratou katoa, i tenei i tenei o ratou, me nga pera katoa e meinga kei a ratou.'

25 TKM, 14 July 1860, p.9: ‘ . . he tutu tera, he whakahihi marire ki te Kuini, a ekore rawa e whakaaetia.'

26 TKM, 14 July 1860 , p.10. 'No konei i meatia ai ko tona tino mahi poauau tenei kia tahuri nga Iwi o Niu Tirani ki te whakawai mo ratou, kia anga ki tetahi mahi e mutu ai to ratou piri ki te Kuini. Kei wehea hoki, na, kua kore nga tikanga e whakawhiwhia nei ratou inaianei i runga i te hononga ki te Iwi o Ingarani, tona tukunga iho hoki, ko nga tini kino ka tau ki runga i te iwi Maori, a te ngaromanga e ngaro rawa ai.'; 'It is therefore the height of folly for the New Zealand tribes to allow themselves to be seduced into the commission of any act which, by violating their allegiance to the Queen, would render them liable to forfeit the rights and privileges which their position as British subjects confers on them, and which would necessarily entail upon them evils ending only in their ruin as a race [source]'.

27 Gore Browne to McLean, 8 August 1860, MS-Papers-0032-0183, object \#1001196, Alexander Turnbull Library (ATL), Wellington.

28 Virginia M. Perry, ed., Eliza's Journal: A Gentlewoman's Experiences in New Zealand in the Late 1850s, Dunedin, n.d., p.249.

29 Memo, Donald McLean, 16 April 1860, MA 1 831/ 1860/34, Archives New Zealand (ANZ), Wellington.

30 Memo, McLean, 1 August 1860, MA1 831 1860/83, ANZ.

31 Parliamentary Debates 1858-1860 [PD], 10 August 1860, p.271.

32 Daily Southern Cross (DSC), 28 August 1860, p.2

33 DSC, 29 June 1860, p.3.

34 Wellington Independent (WI), 20 July 1860, p.3.

35 Memoranda, McLean, Auckland, n.d., MA 1 831/ 1860/34, ANZ. Some chiefs extended their stay, and were examined in Parliament on their views of the Native Offenders Bill. See PD, 24 August 1860, pp.390-81. 


\section{Journal of New Zealand Studies}

36 See Bernard S. Cohn, 'Representing Authority in Victorian India', in Eric Hobsbawm and Terence Ranger eds, The Invention of Tradition, Cambridge, 1993, pp.167-9, 196-200.

37 McLean to Gore Browne, n.d., MS-Papers-0032-0723, object \#1022612, ATL.

38 TKM, 1 September 1860, p.2. 'Tino whakapai ana ratoi i taua tohu aroha'; 'They seemed fully to appreciate this mark of regard [source].' Cohn suggests that in India, 'The closer to the person of the ruler or his representative one stood, the higher one's status': Cohn, 'Representing Authority', p.169.

39 TKM, 1 September 1860, p.20. 'Kahore koutou e mahara kua tinatahi nei tatou ki a te Kawana, kua puta nei hoki ana kupu ki a koutou? Ki te mea ka kai tahi tetahi iwi ki tetahi iwi he whakau tena i te aroha. Me te Karaiti hoki i te mutunga o tana mahi i kai tahi me ana akonga; ko te unga ano ia o te aroha ki nga Apotoro. Kei hea ianei he rerenga mo koutou? kua kai tahi nei ki a te Kawana.'

40 Rēnata Kawepō, Renata's Speech and Letter to the Superintendent of Hawkes Bay on the Taranaki Question: Ko te Korero me te Pukapuka a Renata Tamakihikurangi ki te Kaiwhakahaere Tikanga o nga Pakeha ki Ahuriri, Wellington, 1861.

41 TKM, 14 July 1860, pp.14, 39, 47; 3 August 1860, pp.8, 30; 15 August 1860, p.11; 1 September 1860, p.2.

42 Buller to McLean, 3 September 1860, MS-Papers-0032-0190, object \#1013891, ATL.

43 At this time it was not unusual for New Zealand's English-language newspapers to be just four pages in length. However, these pages were large, about the size of a modern daily newspaper, whereas the dimensions of Te Karere Maori's pages were about 250 x 200mm. See: New Zealand Digital Library, 'Commentary, The Maori Messenger Ko te Karere Maori 1855-1860', Niupepa Māori, www.nzdl.org/niupepa, accessed 12 April 2011.

44 TKM, 14 July 1860, p.2.

45 TKM, 31 July 1860, p.5. 'E rapu ana au ki te tikanga i noho ai tatou ki konei, kei ta Te Rangitake, kei te Kingi ranei.' 'I am searching for the cause that has brought us here. Is it Te Rangitake, or is it the king movement? [source].'

46 WI, 4 September 1860, p.5.

47 TKM, 31 July 1860 , p.46. 'E kawe nei nga tangata o Taranaki ki runga ki te wahi kua riro noa mai ki te Kawanatanga, E kawe ana a Waikato ki te wahi nana i tuku, i te awatea, i horahia hoki e o ratou rangatira, i te ra e whiti ana, i hoatu ki nga ringa o te Pakeha. Mehemea he whenua toitu e pai ana; tena ko tenei, he whenua kua pungarehutia, e kore e taea te whakaora ano, tera e ora nga pungarehu o te ahi kua mate. Ma koutou tenei e rapu, e matakitaki, ma nga rangatira o te runanga nei.'

48 TKM, 3 August 1860, pp.29-30.

49 See TKM, 1 September 1860, pp.26-30, 33-35.

50 TKM, 15 August 1860, p.7. 'Ko tenei Runanga kua rongo nei i nga tikanga i tupu ai te whawhai ki Taranaki, e mea ana i tika ano te whakahaere a te Kawana; tetahi, na Wiremu Kingi Te Rangitake te whakatari ki te pakanga; ko tana whakahaere e kore rawa e ahei te whakatika.'

51 McLean to Gore Browne, 10 August 1860. MS-Papers-0032-0723, object \#1008664, ATL.

52 TKM, 15 August 1860, p.7. 'Ka karanga ano a Te Makarini, "Ko nga tangata e whakaae ana me hapai ite ringa." Ka tupu te pohehe i konei. Ka tahi a Te Makarini Te Uhiniko ka whakatika, ka mea, "Te mea i tu ai ahau, he kitenga noku kahore nga ringaringa o te tokomaha i ara." Kei runga ko Herewini Te Amohau, ka ki atu ki a Te Makarini Te 
Uhiniko, "No mua ano to whakahe i a te Kawana: ko to mahi tonu tena." Ka whakahokia atu e Te Makarini, "Kahore oku whakahe inaianei: i hapainga ano toku ringa.",

53 WI, 20 November 1860, p.3. According to Grey the conference had cost at least $£ 5171$. See Appendices to the Journals of the House of Representatives (AJHR), Session I, 1862, E-01, section II, no.12, p.31.

54 TKM, 15 August 1860, p.5. 'I whakaaetia nuitia enei kupu e te runanga, kotahi tonu te kupu i whakahe atu ai etahi. Ka whakatika atu matou, ta te mea, e tino whakahengia ana e ratou katoa, e te tini o nga rangatira mana, whai whakaaro hoki, tera mahi kuare, te "Kingi Maori." I korerotia hoki e matou tona tikanga i tera Karere.'

55 Te Haeata (TH) 1 September 1860, p.1. 'Kei ta ratou whakaaro, kei ta te tokomaha e nga tangata o taua Runanga, na Te Rangitake te take o te ke ki Taranaki. . . Ta ratou e tino pai ai me piri ki te Pakeha; me aroha ratou ki te Pakeha, me aroha hoki te Pakeha ki te Maori. .. . Tenei tetahi take korero o taua Runanga, ko te mahi whakatu king nei. Ka nui nga kupu whakahe mo tenei wahi: ki a ratou ko te take tenei o nga raruraru o te motu nei . . . kei a ratou me noho katoa nga Maori ki raro i te taumarumarunga o te Kuini, kia kotahi he ture mo te motu nei, kia kotahi mo te Maori mo te Pakeha, kia rite tahi.'

56 Carleton was critical of the war, but as a parliamentarian was prepared to support the government in matters of confidence and supply. See D.B. Silver, 'Carleton, Hugh Francis', Dictionary of New Zealand Biography. Te Ara the Enclopedia of New Zealand, updated 1-Sep-10, http://www.TeAra.govt.nz /en/biographies/1c5/1; John Stenhouse, 'Churches, State, and the New Zealand Wars: 1860-1872, Journal of Law and Religion, 13, 2 (1998), pp.484, 490-2.

57 DSC, 21 August 1860, p.3

58 DSC, 24 August 1860, p.3.

59 DSC, 1 September 1860, p.5.

60 DSC, 24 August 1860, p.3; 28 August 1860, p.2

61 TKM, 1 September 1860, p.16. 'Tenei hoki tenei kupu aku. Kei pouri mai koe e Ma. Kia tukua te mahanatanga ki runga ki te Maori, kia rite ki to te Pakeha.'

62 DSC, 24 August 1860, p.6

63 WI, 26 October 1860, p.2.

64 DSC, 11 September 1860, p.3; PD, 5 September 1860, p.454.

65 DSC, 28 August 1860, p.2. See also Otago Witness (OW), 27 October 1860, p.3.

66 TKM, 15 July 1860, pp.5-6; 15 August 1860, pp.8-9; WI, 4 September 1860, p.5.

67 TKM, 15 July 1860, pp.1-2.

68 Paul Monin, This is My Place: Hauraki Contested 1769-1875, Wellington, 2001, p.172.

69 AJHR, Session I, 1862, E-01, section II, no.14.

70 AJHR, Session I, 1862, E-01, section II.

71 AJHR, Session I, 1862, E-01, section I.

72 AJHR, Session I, 1862, E-01, section I.

73 AJHR, Session I, 1870, A-21; Session II, 1879, G-8.

74 Michael J. Allen, 'Maori Political Thought in the Late Nineteenth Century: A Microhistorical Study of the Document of Speeches from John Balance's Tour of Seven Maori Districts, 1885', MA thesis, University of Canterbury, 2004, pp.4-5. 


\section{Journal of New Zealand Studies}

75 Johnston to McLean, 13 August 1860, MS-Papers-0032-0358, object \#1018042, ATL.

76 Colonist (TC), 7 August 1860, p.3. These sentiments were echoed by some other newspapers, for example the OW, 27 October 1860, p.3.

77 WI, 4 September 1860, p.2.

78 AJHR, Session 1, 1862, E-01, section I.

79 TC, 11 September 1860, p.3. 